Man and Nature

L'homme et la nature

\title{
Shakespeare and Eighteenth-Century German Poetics
}

\section{Hans-Günther Schwarz}

Volume 4, 1985

URI : https://id.erudit.org/iderudit/1011844ar

DOI : https://doi.org/10.7202/1011844ar

Aller au sommaire du numéro

Éditeur(s)

Canadian Society for Eighteenth-Century Studies / Société canadienne d'étude du dix-huitième siècle

ISSN

0824-3298 (imprimé)

1927-8810 (numérique)

Découvrir la revue

Citer cet article

Schwarz, H.-G. (1985). Shakespeare and Eighteenth-Century German Poetics. Man and Nature / L'homme et la nature, 4, 171-182.

https://doi.org/10.7202/1011844ar

Copyright (c) Canadian Society for Eighteenth-Century Studies / Sociéte canadienne d'étude du dix-huitième siècle, 1985
Ce document est protégé par la loi sur le droit d'auteur. L'utilisation des services d'Érudit (y compris la reproduction) est assujettie à sa politique d'utilisation que vous pouvez consulter en ligne.

https://apropos.erudit.org/fr/usagers/politique-dutilisation/ 


\section{Shakespeare and Eighteenth-Century German Poetics}

Shakespearomania was one of the terms used in an unflattering way by the nineteenth century German dramatist, Christian Dietrich Grabbe, to describe the enthusiasm shown by the Storm and Stress movement in the 1770 s for the works of Shakespeare. Gerstenberg, Goethe, Herder and Lenz not only modelled their own plays on Shakespeare's dramas, but also explained and justified Shakespeare as an artist. These explanations and justifications resulted in new ideas which broke the dominance of Aristotelian poetics and laid the foundation for new, modern theories of art and drama.

Gerstenberg, Herder and Lenz $z^{1}$ see Shakespeare's work as the meetingpoint between antiquity and modernity. Earlier attempts by Lessing to fit Shakespeare into a classical mould were not followed up. The ability to appreciate Shakespeare without resorting to classical theory distinguishes German Shakespeare criticism of the eighteenth century from its English counterpart. Gerstenberg in his Briefe über Merkwürdigkeiten der Literatur, 1766, and Herder in his essay Shakespeare, 1773, develop theories of poetry which put Shakespeare and Sophocles side by side without making the latter the measure of the former. Lenz's Die Anmerkungen übers Theater, written in 1771 and printed in 1774, attempts a theory of drama completely outside traditional poetics. ${ }^{2}$ The basis of this first anti-Aristotelian theory is to be found in Shakespeare's works, and past aesthetic norms are no longer considered applicable.

MAN AND NATURE / L'HOMME ET LA NATURE IV/1985

$0824-3298 / 85 / 0400-0171 \$ 01.25^{/ 0}$ C.S.E.C.S./S.C.E.D.S. 
The reaction of these critics towards Shakespeare is a direct result of their reaction to the classicism of the Enlightenment. The departure from classical aesthetics and its normative rules is a gradual process. Oddly enough Winckelmann's studies of Greek art contributed greatly to a new interpretation of Shakespeare. ${ }^{3}$ Winckelmann combines a historical view of art with the traditional universal view of art: he no longer looks at Greek sculptures as timeless paradigms for a normative system of aesthetics, but interprets them in their historical context, and describes them as concretely as possible. Herder's differentiation between modern and antique drama takes Winckelmann's ideas to their logical conclusion. To quote Herder: 'In Griechenland entstand das Drama, wie es in Norden nicht entstehen konnte ... Also Sophocles Drama und Shakespears Drama sind zwei Dinge, die in gewissem Betracht kaum den Namen gemein haben'4 ('In Greece drama was created in a way which could not be followed in the North .... Therefore, Sophocles' dramas and Shakespeare's dramas are two things which in certain respects have nothing in common').

A historical viewpoint is a prerequisite for recognizing Shakespeare as the father of modern drama. Furthermore, such a viewpoint had to dispense with the need for justifying a work of art along classical lines. This attitude is shared by all three writers, Gerstenberg, Lenz and Herder. Their attempts to define Greek drama historically serve to prove that aesthetic norms are valid only in a particular historical context, as is shown by Herder's famous biological metaphor 'dass aus dem Boden der Zeit, eben die andere Pflanze erwuchs's: ('Greek soil produces a different plant from English soil'). In other words, Greek and Shakespearean drama are indeed different because of their respective time and place in history. This remark exemplifies the genetic-historical premise of Storm and Stress criticism. As opposed to Lessing, who prided himself on having reconciled Shakespeare's art with Aristotelian precepts, Herder notes a fundamental difference between Shakespearean and Greek drama: 'Geschichte, Tradition, Sitten, Religion, Geist der Zeit, des Volks, der Rührung, der Sprache - wie weit von Griechenland weg!'b ('history, tradition, manners, religion, spirit of the age, of the people, of the effect on the audience, of the language - how far removed from Greece!'). By using this type of historical argument, Herder explains the character of Greek drama in terms of its origins - the historical, political and geographical conditions of Greece.

Comparing Shakespeare and the Greeks leads Gerstenberg, Lenz and Herder to the insight that literature in its historical evolution is subject to constant change. As a result, collective poetics are no longer considered universal. As the norms followed by the French classicists and their Ger- 
man imitators - that is to say those who opposed Shakespeare - have lost their historical justification, the art produced by the authors is said to be 'artificial' (künstlich) in so far as it follows norms which have lost their historical justification. Only Shakespeare lives up to their demands that art be an immediate expression of nature. Shakespeare, says Herder, is 'immer Diener der Natur'7 ('always a servant of nature'). Gerstenberg sees Shakespeare as a dramatist who describes customs and manners by imitating true characters carefully and faithfully. ${ }^{8}$ Rather than imitating historically irrelevant models, the replacement of art by nature leads to the realism so typical of the Storm and Stress movement.

The emphasis on characteristic rather than idealistic representation and action in Storm and Stress poetics, as well as in dramatic practice, is a result of changes from normative to subjective theories of poetry. The changes are illustrated by the ways in which Lessing and Herder both defend Shakespeare in the face of the Greeks. For Lessing, Shakespeare acquires a stature equal to the Greeks. Like them, he achieves the moral purpose of tragedy. Indeed, Lessing saw the moral purpose of art as a universal concept which he believed was valid at all times and inherent in the dramatic genre. Shakespeare's works find their place alongside the Greeks by fulfilling an abstract normative criterion rather than because of any particular merit of their own. For Herder, however, Shakespeare is the creator of his own world. This is a decisive step, since the artist and his creation become the sole measure of any judgement. Indeed, the appreciation of Shakespeare by the Storm and Stress movement introduces the modern standard for aesthetic judgement. In the writings of Gerstenberg, Herder and Lenz, Shakespeare's plays are interpreted without resorting to any outside criteria. On the contrary, the text alone is sufficient.

With this in view the traditional role of the audience as arbiter diminishes. Wirkungsästhetik - the analysis and judgement of the effect or appeal of a literary work on the reader - greatly decreases in importance during the Storm and Stress movement. The tragic effect, an inheritance from the Aristotelian concept of Katharsis, was still the foundation of Lessing's aesthetic judgements. Following the Aristotelian concepts of fear and pity, Lessing defines tragedy as 'a poem ... which stirs up pity'. Elsewhere he affirms: 'Nur diese Tränen des Mitleids und der sie fühlenden Menschlichkeit sind die Absicht des Trauerspiels's ('The sole intention of a tragedy is to produce tears of pity and stir human emotions'). Therefore a tragedy is valued not so much according to its plot as by the effect it has on the emotions of the viewer. Because of the effect of Shakespeare's works on the audience, Lessing called Shakespeare the greatest tragic genius of modern European culture. 
The role of Shakespeare as a tragic genius is further cemented by the Storm and Stress movement. Cathartic reactions of fear and pity on the part of the audience, however, are no longer seen as a dramaturgical sine qua non. Wirkungsästhetik, although always part of the Storm and Stress movement, is no longer an indispensable characteristic of drama. Admittedly, Shakespeare's effect on the audience is constantly stressed by the movement, especially when its adherents compare his works with the 'Puppe, Nachbild, Affe, Statüe'10 ('marionettes, copies, apes and statues') of the French imitations of classical dramas. But new meaning is given to Shakespeare's effects, as Lenz's observations on the ghost scene in Hamlet demonstrate and which he compares with Voltaire's Sémiramis: 'Wem ist denn nicht bekannt, dass seine Semiramis kein Kind erschreckt hat ... derweile Shakespears Gespenst Weiber kreissen machte, eben weil es durch diesen ungekünstelten Ausdruck des Soldaten vorbereitet war: "Not a mouse stirring"11 ('Is there anybody who does not know, that his Sémiramis never managed to terrify even a child ... whereas Shakespeare's ghost made women give birth, for the very reason that its appearance was prepared by this simple utterance by the soldier "Not a mouse stirring".')

Shakespeare's effects are analysed textually using new methods similar to werkimmanente interpretations or the new criticism which prevails two centuries later. Lenz's emphasis on the element of preparation (Vorbereitung) within the dramatic structure certainly substantiates this. Regarding the recognition-scene in Pericles Lenz remarks: 'Ich frage, ob eine Wiedererkennung rührender sein kann, besonders wenn sie vorbereitet worden, wie sie es durch die Schicksale des unschuldsvollen Mädchens ist, die im vorhergehenden Akt dargelegt werden'12 ('I ask whether any recognition could be more stirring, especially when it was prepared as was this one by the depiction of the misfortunes of the innocent girl in the preceding act'). Concepts such as anticipation and foreboding enter critical vocabulary for the first time. Wirkungsästhetik begins to disappear; in its place Realästhetik, restricting analysis to the artwork as a work of art, comes to the fore.

The degree to which Shakespeare is considered to be outside the traditional Wirkungsästhetik, is evident in the fifteenth letter of the Merkwürdigkeiten der Literatur by Gerstenberg. Gerstenberg compares Shakespeare and Young in accordance with the developing Realästhetik: 'Shakespear bemühte sich, ihre feinsten Nuancen zu entwickeln, und ihre verborgenste Mechanik aufzudecken. Young konzentrierte die aus seiner Materie hervorspringenden Situationen zu der abgezielten Wirkung auf das Gemüt des Zuschauers. Shakespear zeichnete seinen Plan nach dem Effekte, den er auf das Gemüt des Othello machen sollte'13 ('Shakespeare 
strove to develop the nuances of his characters and to uncover their most hidden mechanisms. Young crystalized situations which arise in order to produce specific effects on the minds of the viewers. Shakespeare drew his plan according to the effect it was supposed to have on the mind of Othello'). Shakespeare's plays are interpreted as closed systems and are not subject to any demands or criteria from outside.

On the one hand, historical thinking, which justifies the subjective and the particular, takes the place of normative aesthetics and Wirkungsästhetik. On the other hand, a new concept of man brings about a break with the traditional imitatio principle. The imitation of action is superseded by the imitation of characters. As early as 1741, Johann Elias Schlegel compares Shakespeare's Julius Caesar with the works of the German Baroque author Andreas Gryphius as a means of establishing the difference between traditional action drama and character drama. Schlegel credits Shakespeare with a deeper knowledge of man than Gryphius. Lessing, too, maintains that the characters are more important than the plot. Representation of man as character is necessary in Lessing's view in order to bring about the emotional effect expected of drama. Full emphasis on the imitation of man comes about during the Storm and Stress period. In the Anmerkungen, Lenz revolts against Greek drama, and turns towards a Charaktertragödie of free man and thereby produces an apologia of Shakespeare as the poet of modernity. Actions in modern drama are the result of forces created by man, whereas in the plays of antiquity they are instigated by the gods. Lenz's new view of 'der Held allein ist der Schlüssel zu seinen Schicksalen'14 ('the hero alone is the key to his fate'), which he drew from Shakespeare's works, anticipates romantic art criticism; there, in the writings of August and Friedrich Schlegel and Friedrich Schelling, the character is seen as responsible for his own fate. The complexity of human life freed from transcendental powers was first shown in Shakespeare's plays. The simplicity of the Greek world view is contrasted with an everincreasingly fragmented world-view in modern times. Therefore, unity of action which corresponded to the objective world-view of the Greeks, is no longer Shakespeare's concern, but rather as Lenz puts it, 'die unendliche Mannigfaltigkeit der Handlungen und Begebenheiten in der Welt'15 ('the unending variety of actions and happenings in the world') ... and 'die Mannigfaltigkeit der Charaktere und Psychologien'16 ('the variety of characters and psychologies'). The increasingly anthropocentric attitude demands that characters on stage be as realistic as possible (Ähnlichkeit der handelnden Personen), just as Shakespeare represented them. Shakespeare's realism determines the form of Lenz's dramas as well as the future development of the genre in Germany. This new form, the 
so-called 'open form', thus becomes a historical necessity and not a typical Sturm und Drang aberration, a view commonly held in the nineteenth century.

The Storm and Stress period brings about a change in the perception of Shakespeare's artistic role. Herder's appreciation of Shakespeare is based less on the works and their artistry than on Shakespeare's being a 'creator of world and history'. Gerstenberg, too, is little concerned with Shakespeare as a playwright, because his tragedies are not to be judged 'aus dem Gesichtspunkte der Tragödie, sondern als Abbildungen der sittlichen Natur'17 ('from the viewpoint of a tragedy, but as depictions of human nature'). The works are seen as Nature, rather than as artifact. This view of Shakespeare rests on a concept of God, which in the eighteenth century still subsumes art and artists under transcendental criteria. ${ }^{18}$ The new approach begins with Lenz who anticipates the Shakespeare criticism of the Romantic period, especially that of Friedrich Schlegel, by viewing Shakespeare's plays as works of art.

During the Storm and Stress period, the changing view of Shakespeare's artistic role from genius to 'playwright' reflects a changing concept of art. Even during the earlier period of Rationalism, the notion of genius had been present. The Enlightenment view of the concept of genius is based on the idea of imitatio - an imitation, however, which is completely subjected to norms. For example, Lessing still views artistic creation as an ordering process. The creator of a drama works according to purposes, in the same manner as God works according to purposes, in other words as a rationalist. The Storm and Stress generation develops a new concept of God and of art. The imitatio by the rationalistic genius, who creates in the same way as the God of a rational and perfect universe, is opposed to the new concept of artistic creation; for now the artist becomes a God who creates his world according to his own point of view. Goethe's poem Prometheus is a prime example. The subjective view of art held by the Storm and Stress generation makes a secularized religion out of art.

This new concept of art leads to a new notion of drama. The crisis of tradition is reflected in a crisis of dramatic form. A certain breakdown of form is clearly apparent: not only the poetic practice but also the poetic theory of the Storm and Stress movement apparently derive their impulse from a 'formless' Shakespeare. Herder may serve as an example in his rejection of all theoretical classifications of Shakespeare's plays, since 'die Farben aber schweben da so ins Unendliche hin'19 ('all colours dissolve away into infinity'). More important than dramatic form, according to Herder, is the Hauptempfindung ('primary sentiment') which prevails in every work by Shakespeare 'wie eine Weltseele'20 ('like a world 
soul'). Herder sees Shakespeare's plays as the result, not of a conscious artistic effort, but of a natural creation; but this view is only one aspect of the Storm and Stress appreciation of Shakespeare.

The appreciation of the artistry of Shakespeare's plays as a conscious effort, on the other hand, appears in the writings of Gerstenberg and Lenz. Lenz objected vehemently to the champions of Shakespeare, who 'make us believe that Shakespeare's beauties consisted in his irregularity'. Indeed Shakespeare's irregularity says Lenz, has a 'reason for being' (Beweggründe). Lenz condemns 'junge Dichter, die aus blossem Kützel einem grossen Mann in seinen Sonderbarkeiten nachzuahmen, ohne sich mit seinen Bewegungsgründen rechtfertigen zu können'21 ('young poets who [use the open form and] for sheer gratification imitate the particularities of a great man without being able to justify themselves with his motives'). Gerstenberg, too, stresses the organization and the wholeness of Shakespearean drama. He comments on The Merry Wives: 'Es ist nur eine Haupthandlung da, mit der die Episode nach den regelmässigsten Mustern verflochten ist ...'22 ('There is only one main plot with which the episode is intertwined in the most regular fashion ...'). Shakespeare's unity of artistic intention and form is constantly emphasized: 'Sie werden beständig eine malerische Einheit der Absicht und Composition beobachten, zu der alle Teile ein richtiges Verhältnis haben, und die eine Anordnung zu erkennen geben, welche ... dem Künstler eben so viel Ehre machen, als die vortreffliche Zeichnung der Natur dem Genie $^{23}$ ('you will always observe a picturesque unity of intention and composition, to which all parts are correctly proportioned, and which show an arrangement, which ... honours the artist as much as the excellent depiction of nature honours the genius'). The artistic unity of a Shakespearean composition cannot be cut into parts (lässt sich nicht zerstücken) as Lenz observes. ${ }^{24}$ Lenz's and Gerstenberg's artistic insights anticipate Friedrich Schlegel's famous Hamlet letter of June 19, 1793 with its appreciation of Shakespeare as 'one of the most intentional artists' 25 (einer der absichtlichsten Künstler).

Friedrich Schlegel's question: 'Soll man Shakespeares Werke als Kunst oder als Natur beurteilen ?'26 ('Are Shakespeare's works to be judged as art or as nature?') had already been answered by the theoreticians of the Storm and Stress. Their synthesis of art and nature demands a revision of an opinion held in secondary literature since Gundolf's classic Shakespeare und der deutsche Geist. Gundolf limits the Storm and Stress achievement to an appreciation of Shakespeare's works as nature only; whereas he credits the Romantic movement with understanding Shakespeare's works as art. Present-day research hardly concerns itself at all with the theoretical statements made by the Stürmer und Dränger. ${ }^{27}$ 
This is particularly evident in the various comments concerning the decay of form and, indeed, the decay of drama as a genre. This seeming destruction of traditional dramatic form, and its replacement by the open form and its constituent epic elements, should, however, be seen as a renewal! If Gerstenberg's 'unity of intention and composition' is taken as the underlying artistic motivation for any creation by Sturm and Drang writers, then the new form becomes a point of departure for later writers (Büchner and Brecht). Lapidary style, mixture of styles, tragi-comedy are the rich inheritance from Shakespeare which the Sturm und Drang movement bequeathed to modern German drama.

Of greatest importance for the further development of German drama is a change in the role of the hero. Until the Enlightenment the emphasis was on individual fate. The discrepancy between rising social concerns, their reflection in drama, and traditional dramatic form is solved by changing the dramatic focus from the individual to the depiction of a social process in which the individual is submerged. Lenz's Soldaten is a prime example. The end of tragedy as a genre, in an Aristotelian sense, leads to what critics call bürgerliche Tragik, middle class tragedy, which Lenz, in fact, calls a Komödie. It is Shakespearean comedy which becomes the model for the artistic description of the emerging middleclass society of the eighteenth century. A society which no longer allows individual self-realization makes it poetically impossible to have a hero, a Hauptperson, and therefore Lenz cannot write a tragedy in the old sense of the word. In the Anmerkungen, Lenz mirrors the change both from divine forces shaping man's destiny in antiquity and from the individual mastering his own fate in modernity.

In his view, modern social forces make it impossible for an individual to master his own fate, and they prompt a sharp distinction between comedy and tragedy: 'Die Hauptempfindung in der Komödie ist immer die Begebenheit, die Hauptempfindung in der Tragödie ist die Person, die Schöpfer ihrer Begebenheiten'28 ('The primary focus in a comedy is always the event, the primary focus in a tragedy is the character, the creator of his situation'). Two thousand years of Aristotelian poetics have come to an end with this definition.

The clash between Shakespeare's plays and French classical drama, which is completely oriented towards the nobility, gives German drama a new political meaning. Herder praises Shakespeare's talent for moving 'König und Narren, Narren und König zu dem herrlichen Ganzen'29 ('King and fools, fools and King towards a glorious whole') in King Lear. Lenz describes Shakespeare thus: Mensch, in jedem Verhältnis gleich bewandert, gleich stark, schlug er ein Theater fürs ganze menschliche Geschlecht auf, wo jeder stehen, staunen, sich freuen, sich wiederfinden 
konnte, vom obersten bis zum untersten'30 ('a man at home and equally strong in all circumstances, he built a theatre for all mankind in which everybody - from the highest- to the lowest-placed member of society - could stand, marvel, be delighted, find himself again'). The concept Mensch ('man') becomes the new leading idea in overcoming the class barriers: 'Seine Könige und Königinnen schämen sich so wenig als der niedrigste Pöbel, warmes Blut im schlagenden Herzen zu fühlen ... denn sie sind Menschen' ${ }^{\prime 31}$ ('His kings and queens are no more ashamed than the common mob of feeling warm blood in their beating hearts ... because they are human beings'). A socially aware author, such as Lenz, makes Shakespearean drama socially relevant by focusing on the problems of the middle class. In his plays Die Soldaten and Der Hofmeister, we see a continuation of Shakespeare's tendency to stress the powerlessness of the individual. The individual is seen solely as a plaything of social forces; in creating social drama, Lenz once again anticipates Büchner and Brecht. The loss of a tragic dimension (in both the classical and Shakespearean senses) in the fate of the individual and his new existence within a socio-historical framework give Storm and Stress drama an ideological orientation, which is enhanced by the realism drawn from Shakespeare.

Ever since J.E. Schlegel (1741) applied the word Wahrheit ('truth') to Shakespeare, it became the guiding principle and the catchword for modern German drama. Lenz's dictum: 'Das Theater ist ein Schauspiel der Sinne, nicht des Gedächtnisses, der Einbildungskraft'32 ('Theatre is a play for the senses, not the memory nor the powers of imagination') supports the perennial call for a concrete drama. Shakespeare's realism is described by Gerstenberg: 'bey einer so sorgfältigen Beobachtung der Natur, bey einer so seltenen Richtigkeit in der peinture des details ${ }^{\prime 33}$ ('such a careful observation of nature, such a rare accuracy in the peinture des détails'). Shakespeare's realism cannot exist without open form. In contrast to the classical closed form the open form alone is able to mirror Wahrheit und Ausdruck ('truth and expression') without sinnlichen Betrug ('cheating the senses') ${ }^{34}$. Open form signifies the replacement of the sequential structure of traditional drama by a simultaneous structure, by a montage of disparate elements. Lenz justifies this new form with an example from landscape gardening: 'Es gibt zweierlei Art Gärten, eine die man beim ersten Blick ganz übersieht, die andere da man nach und nach wie in der Natur von einer Abwechselung zur andern fortgeht. So gibt es auch zwei Dramata ... das eine stellt alles aufeinmal und aneinanderhangend vor und ist darum leichter zu übersehen, bei dem andern muss man auf- und abklettern wie in der Natur' ${ }^{35}$ ('There are two examples of gardens, one which one can survey at a glance, another 
where you wander, like in nature from one diversion to the next. In this manner there are also two types of drama ... one presents everything at once and in sequence and is therefore easier to survey, in the case of the other you have to climb up and down just as in nature').

The open form as a manifestation of nature is seen as contradicting the artifice of French taste. Gerstenberg quotes from Shakespeare in support of the open form:

'I have heard say there is an art, which in their piedness shares with great creating Nature ....'36

The natural form of Shakespeare's plays, which the Storm and Stress movement strives for in theory and practice, reflects the substance of a modern world which has no objective values. It was therefore unavoidable that Shakespeare's plays determined the form of modern German drama.

HANS-GÜNTHER SCHWARZ

Dalhousie University

Notes

1 Gerstenberg, Herder and Lenz mark three progressive stages within a novel and fairly unified approach to Shakespeare. Goethe has not been included as his famous speech Zum Shakespeares-Tag derives largely from Herder's thinking. (cf. Kurt Ermann, Goethes Shakespeare-Bild (Tübingen: Niemeyer, 1983), pp. 21-53). Schiller, Klinger, Wagner while being important exponents of the literary movement do not contribute anything of significance to our topic.

2 Hans-Günther Schwarz, 'Lenz, Herder und die ästhetisch-poetologischen Folgen,' in Ein Theatermann. Festschrift für Rolf Badenhausen, ed. Ingrid Nohl (München, 1977), pp. 225-230. For a comprehensive study of the relationship Lenz-

Shakespeare, cf. Eva Maria Inbar, 'Shakespeare in Deutschland: Der Fall Lenz', Studien zur Deutschen Literatur, 76 (Tübingen: Niemeyer, 1982). Inbar, however, does not deal with the problems of poetic theory raised in this paper.

3 Peter Szondi, Poetik und Geschichtsphilosophie I, ed. Senta Metz and HansHagen Hildebrand (Frankfurt: Suhrkamp, 1974), p. 24.

4 Johann Gottfried Herder, Sämtliche Werke, ed. Bernhard Suphan (Berlin: Weidmann, 1891), V, 209-210. Owing to the non-existence of English translations of the works under consideration here, all quotations have been translated into English by myself. I gratefully acknowledge the assistance of my colleague, Dr. Elizabeth Spence. 
5 Herder, p. 218.

6 Herder, p. 217.

7 Herder, p. 222.

8 Heinrich Wilhelm von Gerstenberg, Briefe über Merkwürdigkeiten der Literatur, (Hildesheim, New York: Olms, 1971), p. 219.

9 Quotation taken from: Gundolf, Shakespeare und der deutsche Geist (Berlin: Georg Bondin, 1922), p. 128.

10 Herder, p. 213.

11 Jakob Michael Reinhold Lenz, Werke und Schriften, ed. Britta Titel and Hellmut Haug (Stuttgard: Goverts, 1966), I, 371.

12 Lenz, p. 374.

13 Gerstenberg, p. 225.

14 Lenz, p. 360.

15 Lenz, p. 351.

16 Lenz, p. 351.

17 Gerstenberg, p. 239.

18 On the relationship between aesthetics and theology, cf. Hans Peter Herrmann, Naturnachahmung und Einbildungskraft (Bad Homburg, Berlin, Zürich: Gehlen, 1970), pp. 205-224.

19 Herder, p. 230.

20 Herder, p. 224.

21 Lenz, p. 363.

22 Gerstenberg, p. 286.

23 Gerstenberg, p. 302.

24 Lenz, p. 356.

25 Friedrich Schlegel, 1794-1802. Seine prosaischen Jugendschriften, ed. J. Minor (Wien: Konegen, 1906), II, 393.

26 Kritische Friedrich Schlegel Ausgabe, ed. E. Behler (Paderborn, München, Wien: Schöningh, 1958), II, 172-n. 121.

27 Bruno Markwardt, Geschichte der deutschen Poetik II (Berlin: de Gruyter, 1956) offers a wealth of material, but falls short in the interpretation. A good basis is provided by Fritz Martini, 'Die Poetik des Dramas im Sturm und Drang,' in Deutsche Dramentheorien I, ed. Reinhold Grimm (Frankfurt: Athenäuum, 1971), pp. 123-166, and his: 'Die Einheit der Konzeption in J.M.R. Lenz' Anmerkungen übers Theater', in Jahrbuch der Schillergesellschaft 14 (1970), pp. 159-182.

28 Lenz, p. 359.

29 Herder, p. 218. 
30 Lenz, p. 362.

31 Lenz, p. 362.

32 Lenz, p. 367.

33 Gerstenberg, p. 256.

34 Lenz, p. 367.

35 Lenz, p. 466.

36 Gerstenberg, p. 257. 